\title{
Association between heroin use, needle sharing and tattoos received in prison with hepatitis $B$ and $C$ positivity among street-recruited injecting drug users in New Mexico, USA
}

\author{
M. C. SAMUEL ${ }^{1,2 *}$, P. M. DOHERTY ${ }^{1}$, M. BULTERYS ${ }^{3,4}$ AND S. A. JENISON ${ }^{1}$ \\ ${ }^{1}$ Public Health Division, New Mexico Department of Health, Santa Fe, New Mexico \\ ${ }^{2}$ Currently with the California Department of Health Services, STD Control Branch, Berkeley, California \\ ${ }^{3}$ University of New Mexico School of Medicine, Albuquerque, New Mexico \\ ${ }^{4}$ Currently with Division of HIV/AIDS Prevention, National Center for HIV, STD and TB Prevention, \\ Centers for Disease Control and Prevention, Atlanta, Georgia
}

(Accepted 10 July 2001)

\section{SUMMARY}

This study aimed to assess the seroprevalence and risk factors for hepatitis B virus (HBV), hepatitis $\mathrm{C}$ virus (HCV), and HIV-1 infections among injecting drug users (IDU) in New Mexico. Serological and behavioural surveys were conducted in conjunction with street-based outreach, education and HIV counselling and testing. High rates of antibody positivity for HCV $(82.2 \%)$ and HBV (61.1\%), and a low rate for HIV (0.5\%) were found. In multivariate analyses, both HBV and HCV infection were positively associated with increasing age, increasing years of injection and heroin use. Receipt of a tattoo in prison/jail was associated with HBV (odds ratio $=2 \cdot 3,95 \%$ confidence interval $1 \cdot 4,3 \cdot 8)$ and $\mathrm{HCV}(\mathrm{OR}=3 \cdot 4,95 \%$ $\mathrm{CI}=1 \cdot 6,7 \cdot 5)$ infections. Prevention of bloodborne pathogens among IDUs should focus on young users, early in their drug use experience. Studies examining the relationship between tattooing and $\mathrm{HBV}$ and $\mathrm{HCV}$ infection are needed as are efforts to promote sterile tattooing, in prisons and elsewhere.

\section{INTRODUCTION}

The injection of illicit drugs contributes significantly to the epidemic of bloodborne infections in the United States and many other countries [1-3]. Viruses transmitted by using contaminated injection equipment include HBV, HCV, and HIV. Fear of HIV transmission in particular has heightened awareness of the importance of injecting drug use as a source of these viral infections $[4,5]$. In many settings, injecting drug users (IDUs) have been capable of reducing their risk behaviour in the face of the HIV epidemic $[6,7]$. Nevertheless, transmission of hepatitis viruses, especially $\mathrm{HCV}$, has continued unabated among young

* Author for correspondence: Dr Michael C. Samuel, CA DHS STD Control Branch, 1947 Center Street, Suite 201, Berkeley, CA 94704, USA.
IDUs, even in settings where prevention measures have contributed to the maintenance of a low prevalence and incidence of HIV-1 [7].

Practices associated with injecting drug use, particularly sharing contaminated injection equipment, are the most important risk factors for acquiring $\mathrm{HCV}$ infection in the United States [8,9], and persons infected with $\mathrm{HCV}$ are at substantial risk for chronic hepatitis, cirrhosis and hepatocellular carcinoma [10-12].

Continued high prevalence of $\mathrm{HBV}$ and $\mathrm{HCV}$ infections among young adult IDUs raises questions about the timing of viral infection after initiation of injecting drug use and the importance of risk behaviours on the prevalence of hepatitis infections, after adjustment for the duration of injecting drug use. Certain practices and risk behaviours, such as 
sharing of injection equipment and using non-sterile syringes, may be particularly amenable to intervention [13].

A study in 1982 at the Penitentiary of New Mexico indicated that $47 \%$ of inmates had been infected with HBV. Positivity was significantly associated with injecting drug use and with tattoos, but the latter association did not reach statistical significance [14]. Subsequent work in New Mexico suggested high rates of $\mathrm{HBV}$ and $\mathrm{HCV}$ infection but low levels of HIV/AIDS among injecting drug users [15]. It was in the context of this information that data were collected from a street-based outreach and serological testing programme for mostly Hispanic IDUs at urban and rural locations in New Mexico. Behavioural characteristics independently associated with $\mathrm{HBV}$ and $\mathrm{HCV}$ positivity were analysed after adjustment for age and duration of injecting drug use.

\section{METHODS}

\section{Study population}

During 1995-7, three IDU outreach programmes were conducted by the New Mexico Department of Health. These programmes recruited convenience samples through a public health HIV counselling and testing outreach initiative. Several community-based organizations working with IDUs collaborated in recruiting participants for the street-based programmes. Voluntary anonymous HIV counselling and testing, HBV and HCV testing, along with harm reduction education, were provided during the outreach. The programmes were conducted in three regions of New Mexico (Fig. 1): the Las Cruces area in rural southwest New Mexico, close to the Texas and Mexico borders (1995); Albuquerque, Bernalillo County, in central New Mexico (1996); and four rural southeast New Mexico counties including the towns of Roswell, Hobbs, Clovis and Carlsbad (1997). All sites in each region were chosen based on evidence of the presence of a sizeable IDU population. In Albuquerque, the sites were determined, in part, by zip code data from a public methadone clinic where an HIV antibody survey had been conducted since 1989.

Mobile vans were used at the study sites for phlebotomy and pretest voluntary HIV and hepatitis counselling activities. Participants were recruited by outreach workers talking to the IDU community and by fliers advertising HIV and hepatitis testing. The date and time indicating when the vans would be in a particular neighbourhood were also listed on the flier.

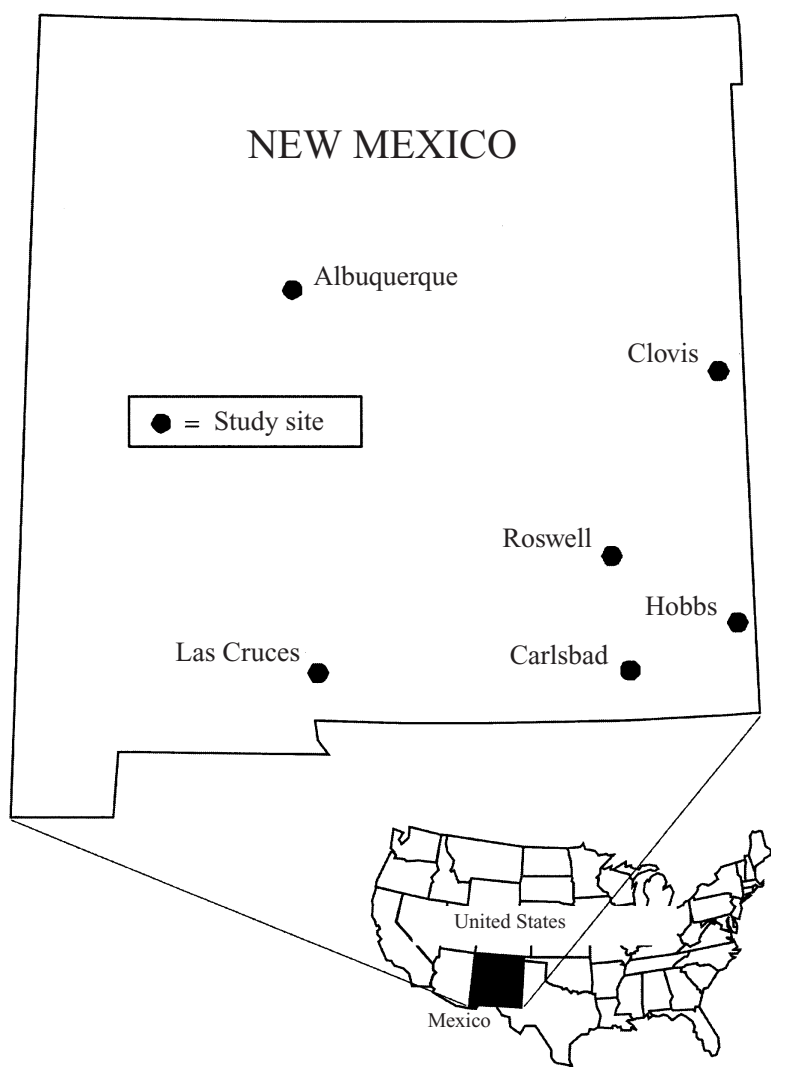

Fig. 1. Map of study sites in New Mexico.

Prior to pretest counselling, all participants received a harm reduction educational session conducted in English or Spanish by a trained outreach worker. Subjects were also given a 'survival kit' containing bleach, water, a drug 'cooker' (a small metal vessel for dissolving drug), condoms, condom lubricant, and resource material on how to clean injection equipment. All participants, who were either IDUs or a sex partner of an IDU present at the site, received payment for a complete interview and blood sample and for returning to the site to obtain their HIV, HBV and HCV test results. IDUs and their sex partners who returned for results were offered HBV and hepatitis A virus (HAV) vaccine at no charge.

Recent injecting drug use was verified by both physical evidence ('track' marks - superficial vein thrombophlebitis) and by asking the participant the process of injecting the drug. Participants were given a unique identification number that was linked to their questionnaire and blood samples in order to obtain HIV and hepatitis virus blood test results. As part of the outreach programme, a survey was administered by trained interviewers which collected demographic and behavioural data. Standard information collected included: race/ethnicity, age, 
Table 1. Demographic characteristics and their association with $H B V$ and $H C V$ antibody positivity among injection drug users, New Mexico, 1995-7

\begin{tabular}{|c|c|c|c|c|c|c|}
\hline & \multicolumn{2}{|c|}{ Study $\left(n=1003^{*}\right)$} & \multicolumn{2}{|c|}{ Hepatitis $\mathrm{B}\left(n=950^{*}\right)$} & \multicolumn{2}{|c|}{ Hepatitis C $\left(n=945^{*}\right)$} \\
\hline & No. & $\%$ & $\%$ pos. & $P$-value $\dagger$ & $\%$ pos. & $P$-value $\dagger$ \\
\hline \multicolumn{7}{|l|}{ Study Site } \\
\hline Southwest (1995) & 229 & $22 \cdot 8$ & $61 \cdot 9$ & \multirow[t]{3}{*}{$<0.001$} & $83 \cdot 0$ & \multirow[t]{3}{*}{$<0.001$} \\
\hline Bernalillo (1996) & 516 & $51 \cdot 4$ & $66 \cdot 4$ & & $88 \cdot 3$ & \\
\hline Southeast (1997) & 258 & $25 \cdot 7$ & $50 \cdot 0$ & & $70 \cdot 0$ & \\
\hline \multicolumn{7}{|l|}{ Race/ethnicity } \\
\hline Hispanic (white) & 733 & $73 \cdot 3$ & $65 \cdot 2$ & \multirow[t]{4}{*}{$<0.001$} & $86 \cdot 3$ & \multirow[t]{4}{*}{$<0 \cdot 001$} \\
\hline White (non-Hispanic) & 184 & $18 \cdot 4$ & $50 \cdot 8$ & & $76 \cdot 7$ & \\
\hline African-American & 46 & $4 \cdot 6$ & $44 \cdot 4$ & & $53 \cdot 3$ & \\
\hline American Indian & 37 & $3 \cdot 7$ & $54 \cdot 1$ & & $67 \cdot 6$ & \\
\hline \multicolumn{7}{|l|}{ Gender } \\
\hline Male & 727 & $72 \cdot 5$ & $64 \cdot 3$ & \multirow[t]{2}{*}{$<0.001$} & $84 \cdot 6$ & \multirow[t]{2}{*}{$0 \cdot 001$} \\
\hline Female & 276 & $27 \cdot 5$ & $51 \cdot 8$ & & $75 \cdot 4$ & \\
\hline \multicolumn{7}{|l|}{ Age group (years) } \\
\hline $15-19$ & 38 & $3 \cdot 8$ & $13 \cdot 5$ & \multirow[t]{8}{*}{$<0.001$} & $29 \cdot 7$ & \multirow[t]{8}{*}{$<0.001$} \\
\hline $20-24$ & 76 & $7 \cdot 6$ & $25 \cdot 3$ & & $53 \cdot 3$ & \\
\hline $25-29$ & 116 & $11 \cdot 6$ & $43 \cdot 2$ & & $79 \cdot 3$ & \\
\hline $30-34$ & 162 & $16 \cdot 2$ & $61 \cdot 3$ & & $86 \cdot 3$ & \\
\hline $35-39$ & 233 & $23 \cdot 2$ & $65 \cdot 0$ & & $86 \cdot 9$ & \\
\hline $40-45$ & 187 & $18 \cdot 6$ & $74 \cdot 2$ & & $90 \cdot 9$ & \\
\hline $45+$ & 191 & $19 \cdot 0$ & $78 \cdot 9$ & & $89 \cdot 4$ & \\
\hline Total & 1003 & $100 \cdot 0$ & $61 \cdot 1$ & & $82 \cdot 2$ & \\
\hline
\end{tabular}

* Basis of $\%$ s and $P$-value may have slightly smaller $n$ due to missing values.

$\dagger P$-values are based on $\chi^{2}$ general test of independence, except for age ( $\chi^{2}$ trend test).

sharing of injection equipment (lifetime), person(s) they primarily shared with (current), length of time injecting, primary drug injected (current), presence of tattoo(s), venue for tattooing and other behaviours possibly related to transmission of blood-borne pathogens.

\section{Laboratory testing}

Venepuncture was the preferred method of blood collection; finger-stick onto filter paper was also available for participants who either did not want a venepuncture or on whom the phlebotomist could not obtain a venipuncture. Only 11 participants $(1 \%)$ had fingersticks for testing on filter paper. All HIV testing was anonymous, using standard New Mexico Department of Health counselling and testing protocols. When the participant returned for serological results a 'limited service record' with identifying information was completed if they were eligible for HBV vaccine (negative for antibodies to hepatitis B surface and core antigens), but this information was not linked to the HIV test results. If sufficient specimen was available, blinded testing was performed for HBV
(anti-HBc and $\mathrm{HBsAg}$ ) and $\mathrm{HCV}$ antibodies among those not requesting hepatitis virus results. Hepatitis testing was not performed for specimens collected on filter paper.

Enzyme immunoassay kits for the detection of the following analytes were used: total antibody to hepatitis B core antigen (anti-HBc) (Genetic Systems Corporation, Redmond, WA), hepatitis B surface antigen (HBsAg) (Genetic Systems Corporation, Redmond, WA), antibody to HCV (anti-HCV) (Abbott Laboratories, Abbott Park, IL), and HIV-1 antibody (Genetic Systems Corporation, Redmond, WA). Serum samples that were repeatedly reactive for antibody to HIV-1 by EIA were further tested by an HIV-1 Western Blot assay (Bio Rad Clinical Division, Hercules, CA) and/or by an indirect fluorescent antibody test (Waldheim Pharmazeutika, Austria) according to established protocols. For hepatitis B only anti-HBc results are presented here.

\section{Statistical analysis}

Data were entered into an Epi-Info database and analysed in SPSS version 8.0. Standard $\chi^{2}$ and $\chi^{2}$ 
Table 2. Behavioural characteristics and their association with $H B V$ and $H C V$ antibody positivity among injection drug users, New Mexico, 1995-7

\begin{tabular}{|c|c|c|c|c|c|c|}
\hline & \multicolumn{2}{|c|}{ Study } & \multicolumn{2}{|c|}{ Hepatitis B } & \multicolumn{2}{|c|}{ Hepatitis C } \\
\hline & No. & $\%$ & $\%$ pos. & $P$-value $\dagger$ & $\%$ pos. & $P$-value $\dagger$ \\
\hline \multicolumn{7}{|c|}{ Share injection equipment } \\
\hline Yes & 903 & $90 \cdot 0$ & $63 \cdot 7$ & \multirow[t]{2}{*}{$<0 \cdot 001$} & $85 \cdot 2$ & \multirow[t]{2}{*}{$<0.001$} \\
\hline No & 100 & $10 \cdot 0$ & $38 \cdot 1$ & & $56 \cdot 3$ & \\
\hline \multicolumn{7}{|l|}{ Share primarily with } \\
\hline Family (not spouse) & 83 & $9 \cdot 2$ & $57 \cdot 7$ & \multirow[t]{5}{*}{$0 \cdot 09$} & $83 \cdot 3$ & \multirow[t]{5}{*}{$0 \cdot 4$} \\
\hline Primary sex partner & 279 & $30 \cdot 9$ & $60 \cdot 1$ & & $87 \cdot 5$ & \\
\hline Friend & 470 & $52 \cdot 0$ & $66 \cdot 9$ & & $85 \cdot 0$ & \\
\hline Anonymous contact & 16 & $1 \cdot 8$ & $81 \cdot 3$ & & $87 \cdot 5$ & \\
\hline Other & 55 & $6 \cdot 1$ & $56 \cdot 9$ & & $76 \cdot 5$ & \\
\hline \multicolumn{7}{|l|}{ Primary drug(s) used } \\
\hline Heroin and cocaine & 516 & $51 \cdot 4$ & $66 \cdot 9$ & \multirow[t]{4}{*}{$<0.001$} & $87 \cdot 4$ & \multirow[t]{4}{*}{$<0 \cdot 001$} \\
\hline Heroin only & 346 & $34 \cdot 5$ & $64 \cdot 6$ & & $85 \cdot 8$ & \\
\hline Cocaine only & 112 & $11 \cdot 2$ & $32 \cdot 7$ & & $60 \cdot 0$ & \\
\hline Other & 29 & $2 \cdot 9$ & $31 \cdot 0$ & & $39 \cdot 3$ & \\
\hline \multicolumn{7}{|l|}{ Years of injection* } \\
\hline $1-4$ & 121 & $15 \cdot 7$ & $23 \cdot 5$ & \multirow[t]{7}{*}{$<0.001$} & $51 \cdot 7$ & \multirow[t]{7}{*}{$<0 \cdot 001$} \\
\hline $5-9$ & 77 & $10 \cdot 0$ & $36 \cdot 8$ & & $63 \cdot 2$ & \\
\hline $10-14$ & 131 & $17 \cdot 0$ & $53 \cdot 6$ & & $86 \cdot 2$ & \\
\hline $15-19$ & 106 & $13 \cdot 8$ & $68 \cdot 8$ & & $91 \cdot 7$ & \\
\hline $20-24$ & 111 & $14 \cdot 4$ & $78 \cdot 8$ & & $92 \cdot 4$ & \\
\hline $25-29$ & 121 & $15 \cdot 7$ & $82 \cdot 1$ & & $97 \cdot 3$ & \\
\hline $30+$ & 103 & $13 \cdot 4$ & $82 \cdot 5$ & & $90 \cdot 6$ & \\
\hline \multicolumn{7}{|l|}{ Tattoo* } \\
\hline Yes & 577 & $74 \cdot 6$ & $63 \cdot 9$ & \multirow[t]{2}{*}{$0 \cdot 003$} & $84 \cdot 8$ & \multirow[t]{2}{*}{$0 \cdot 001$} \\
\hline No & 196 & $25 \cdot 4$ & $51 \cdot 4$ & & $73 \cdot 3$ & \\
\hline \multicolumn{7}{|l|}{ Venue for tattooing* } \\
\hline Friend/self & 292 & $50 \cdot 6$ & $56 \cdot 5$ & \multirow[t]{4}{*}{$<0.001$} & $80 \cdot 4$ & \multirow[t]{4}{*}{$<0.001$} \\
\hline Jail/prison & 217 & $37 \cdot 6$ & $76 \cdot 7$ & & $93 \cdot 2$ & \\
\hline Parlor & 47 & $8 \cdot 1$ & $55 \cdot 8$ & & $72 \cdot 7$ & \\
\hline Other & 21 & $3 \cdot 6$ & $52 \cdot 4$ & & $85 \cdot 7$ & \\
\hline \multicolumn{7}{|c|}{ Number of sexual partners } \\
\hline 0 & 65 & $6 \cdot 5$ & $72 \cdot 1$ & \multirow[t]{7}{*}{$<0.001$} & $91 \cdot 7$ & \multirow[t]{7}{*}{$<0 \cdot 001$} \\
\hline 1 & 436 & $43 \cdot 6$ & $66 \cdot 6$ & & $88 \cdot 1$ & \\
\hline 2 & 117 & $11 \cdot 7$ & $64 \cdot 9$ & & $85 \cdot 7$ & \\
\hline $3-4$ & 161 & $16 \cdot 1$ & $60 \cdot 3$ & & $78 \cdot 1$ & \\
\hline $5-9$ & 108 & $10 \cdot 8$ & $39 \cdot 4$ & & $67 \cdot 0$ & \\
\hline $10-49$ & 94 & $9 \cdot 4$ & $48 \cdot 9$ & & $68 \cdot 1$ & \\
\hline $50+$ & 20 & $2 \cdot 0$ & $55 \cdot 6$ & & $83 \cdot 3$ & \\
\hline
\end{tabular}

* Only included in 1996 and 1997 survey (base $n=774$ ).

$\dagger P$-values are based on $\chi^{2}$ general test of independence, except for years of injection and number of sexual partners $\left(\chi^{2}\right.$ trend test).

trend tests were performed to assess the univariate relationship of demographic and behavioural variables and HBV and HCV seroprevalence. Variables that were significant $(P<0.05)$ were entered into logistic regression models to assess the independent association of these variables with $\mathrm{HBV}$ and $\mathrm{HCV}$ seropositivity. Variables retained in the final models were significant at $P<0.05$ or, in the case of sharing injection equipment and $\mathrm{HBV}$, retained in the model because of well-documented association with infection. All variables were categorical except age and years of injection, which were included as a continuous quadratic function (i.e. age $+\mathrm{age}^{2}$ ). A number of different codings of both age and year of injection were examined, including continuous linear, 'dummy' coding each variable grouped as in Table 1 and 2, and 
the continuous quadratic that is presented. Model goodness-of-fit was based on the log likelihood statistic [16].

Exploratory models examining $\mathrm{HBV}$ and $\mathrm{HCV}$ monoinfection and $\mathrm{HBV} / \mathrm{HCV}$ coinfections were also assessed. In these models the same independent variables were included as the models above. For all these models the dependent variable 'non-infected' ( or ' 0 ') level was persons not infected with either HBV or HCV, and the 'infected' (or ' 1 ') level was either HBV only, HCV only or both HBV and HCV.

\section{RESULTS}

A total of 1062 individuals participated in street-based serological testing programmes targetting IDUs in New Mexico during 1995-7. Of these, 1003 (94\%) were current IDUs. The remaining 59 individuals were sexual partners and other persons seeking testing at the street-based sites and were excluded from all analyses.

Blood specimens were collected from all active injecting drug users, although not every specimen was of sufficient quantity to allow for all serological tests to be performed. For HIV antibodies, $1003(100 \%)$ specimens were tested; for HBV antibodies (anti$\mathrm{HBc}), 950(95 \%)$ were tested; and for HCV antibodies, 945 (94\%) were tested.

The IDU participants were primarily Hispanic $(73 \cdot 3 \%)$, male $(72 \cdot 5 \%)$, and with median age 37 years (range 15-68, interquartile range 30-43) (Table 1). A majority of participants were from Albuquerque in Bernalillo County $(51 \cdot 4 \%), 22.8 \%$ were from the Las Cruces/rural Southwest area, and 25.7\% were from the rural Southeast area (Table 1). This geographic distribution reflects, in part, the large population of Bernalillo County, with over one-third of New Mexico's population and the largest metropolitan area, Albuquerque.

The primary behavioural risk characteristics of the survey population are described in Table 2. Ninety percent of the IDUs reported sharing injection equipment, primarily with friends $(52.0 \%)$ or their main sex partner $(30.9 \%)$. Heroin was the primary drug used by $85.9 \%$ of IDUs, injected either alone or mixed with cocaine. Most participants reported having injected drugs for many years (median 17 years, range 1-51, interquartile range 9-25). Tattoos were very common $(74.6 \%)$ with most tattoos received from a friend or self $(50.6 \%)$ and many received inside jail or prison $(37.6 \%)$.
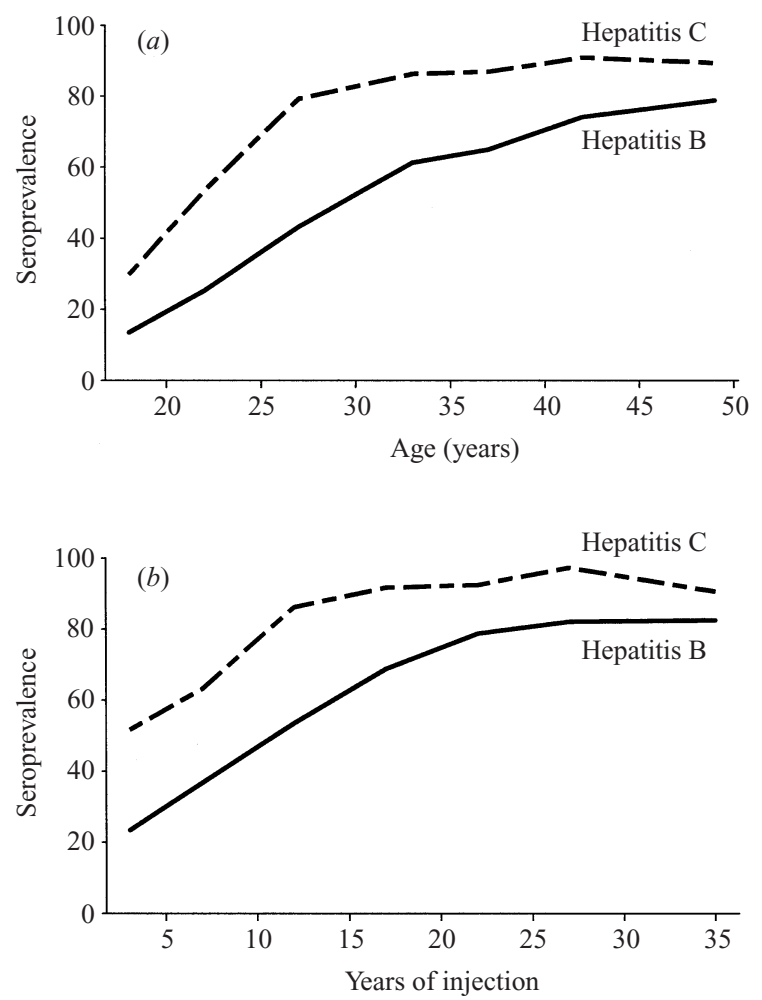

Fig. 2. (a) HBV and HCV antibody prevalence by age group; injection drug users, New Mexico, 1995-7. (b) HBV and $\mathrm{HCV}$ antibody prevalence by years of injection; injection drug users, New Mexico, 1995-7. Age grouped as in Table 1, plotted at median of each group. Years of infection grouped as in Table 1, plotted at median of each group.

The overall rate of antibody positivity among IDUs for HIV was $0.5 \%(5 / 1003,95 \%$ CI $0 \cdot 2-1 \cdot 2 \%)$; for $\mathrm{HBV}$ the anti-HBc positivity was much higher, $61 \cdot 1 \%$ (580/950, 95\% CI 57.9-64.2\%); and for HCV higher yet with $82 \cdot 2 \%(777 / 945,95 \%$ CI $79 \cdot 6-84 \cdot 6 \%)$ antibody positive. The number of tests performed for these three viruses differed because of specimen availability. Because the number of HIV infected participants was small, no statistical comparisons were conducted. Among the $5 \mathrm{HIV}$ positive individuals, 4 were male and 1 female; 3 were Hispanic, 1 was non-Hispanic white, and 1 African American; 4 were from Bernalillo County and 1 was from the Southeast; their ages were between 25 and 32 years; 2 reported sharing injection equipment. The number of sexual partners during the last year reported by each HIV-positive individual was $0,1,3,20$ and 100 .

The prevalence of both HBV and HCV was highest in Bernalillo County and lowest in the Southeast. It was highest in Hispanics and lowest in blacks. It was higher in men than in women (Table 1). Seroprevalence increased strikingly with age: for HBV 
Table 3. Unadjusted and adjusted odds ratios for factors associated with $H B V$ and $H C V$ antibody positivity among injection drug users, New Mexico, 1996-7

\begin{tabular}{|c|c|c|c|c|c|c|}
\hline & \multirow{2}{*}{$\begin{array}{l}\text { Unadj. } \\
\text { OR* }\end{array}$} & \multicolumn{2}{|c|}{$\begin{array}{l}\text { Hepatitis } B \\
\text { Multivariate adjusted }\end{array}$} & \multirow{2}{*}{$\begin{array}{l}\text { Unadj. } \\
\text { OR* }\end{array}$} & \multicolumn{2}{|c|}{$\begin{array}{l}\text { Hepatitis } \mathrm{C} \\
\text { Multivariate adjusted }\end{array}$} \\
\hline & & OR & $95 \% \mathrm{CI}$ & & OR & $95 \%$ CI \\
\hline Study site & $2 \cdot 0$ & - & - & $3 \cdot 2$ & $2 \cdot 1$ & $1 \cdot 3-3 \cdot 6$ \\
\hline \multicolumn{7}{|l|}{ Race/ethnicity } \\
\hline Hispanic (white) & $1 \cdot 6$ & $-\dagger$ & - & $2 \cdot 0$ & $1 \cdot 6$ & $0 \cdot 9-2 \cdot 9$ \\
\hline White (non-Hispanic) & $1 \cdot 0$ & - & - & $1 \cdot 0$ & $1 \cdot 0$ & - \\
\hline African American & $0 \cdot 8$ & - & - & $0 \cdot 4$ & $0 \cdot 3$ & $0 \cdot 1-0 \cdot 8$ \\
\hline American Indian & $1 \cdot 0$ & - & - & $0 \cdot 6$ & $0 \cdot 2$ & $0 \cdot 1-0 \cdot 6$ \\
\hline \multicolumn{7}{|l|}{ Age } \\
\hline 15-19 & $1 \cdot 0$ & $1 \cdot 0$ & - & $1 \cdot 0$ & $1 \cdot 0$ & - \\
\hline $20-24$ & 1.9 & 1.5 & $1 \cdot 1-2 \cdot 0$ & $1 \cdot 6$ & $1 \cdot 4$ & $1 \cdot 0-2 \cdot 0$ \\
\hline $25-29$ & $5 \cdot 8$ & $2 \cdot 2$ & $1 \cdot 2-3 \cdot 9$ & $6 \cdot 4$ & $2 \cdot 1$ & $1 \cdot 1-3 \cdot 9$ \\
\hline $30-34$ & $11 \cdot 3$ & $3 \cdot 4$ & $1 \cdot 5-7 \cdot 6$ & $12 \cdot 7$ & $3 \cdot 0$ & $1 \cdot 3-7 \cdot 1$ \\
\hline $35-39$ & $15 \cdot 7$ & $4 \cdot 3$ & $1 \cdot 8-10 \cdot 4$ & $15 \cdot 4$ & $3 \cdot 6$ & $1 \cdot 4-9 \cdot 3$ \\
\hline $40-44$ & $22 \cdot 8$ & $5 \cdot 4$ & $2 \cdot 1-14 \cdot 0$ & $20 \cdot 9$ & $4 \cdot 2$ & $1 \cdot 6-11 \cdot 4$ \\
\hline $45+$ & $32 \cdot 4$ & 6.9 & $2 \cdot 6-17 \cdot 9$ & $18 \cdot 6$ & $4 \cdot 7$ & $1 \cdot 6-13 \cdot 3$ \\
\hline Share injection equipment & $2 \cdot 4$ & $1 \cdot 3$ & $0 \cdot 7-2 \cdot 3$ & $4 \cdot 7$ & $2 \cdot 8$ & $1 \cdot 5-5 \cdot 4$ \\
\hline Use of heroin & $3 \cdot 9$ & $2 \cdot 4$ & $1 \cdot 4-4 \cdot 0$ & $5 \cdot 5$ & $2 \cdot 5$ & $1 \cdot 4-4 \cdot 6$ \\
\hline \multicolumn{7}{|l|}{ Years of injection } \\
\hline $1-4$ & $1 \cdot 0$ & $1 \cdot 0$ & - & $1 \cdot 0$ & $1 \cdot 0$ & - \\
\hline $5-9$ & 1.9 & $1 \cdot 6$ & $1 \cdot 3-2 \cdot 0$ & $1 \cdot 6$ & $1 \cdot 8$ & $1 \cdot 4-2 \cdot 4$ \\
\hline $10-14$ & $3 \cdot 8$ & $2 \cdot 7$ & $1 \cdot 8-3 \cdot 9$ & $5 \cdot 8$ & $3 \cdot 4$ & $2 \cdot 1-5 \cdot 4$ \\
\hline $15-19$ & $7 \cdot 2$ & $3 \cdot 9$ & $2 \cdot 3-6 \cdot 4$ & $10 \cdot 3$ & $5 \cdot 0$ & $2 \cdot 7-9 \cdot 3$ \\
\hline $20-24$ & $12 \cdot 1$ & $4 \cdot 9$ & $2 \cdot 8-8 \cdot 7$ & $11 \cdot 3$ & $6 \cdot 3$ & $3 \cdot 1-12 \cdot 5$ \\
\hline $25-29$ & $15 \cdot 0$ & $5 \cdot 6$ & $3 \cdot 1-10 \cdot 1$ & $33 \cdot 3$ & $6 \cdot 4$ & $3 \cdot 0-13 \cdot 7$ \\
\hline $30+$ & $15 \cdot 3$ & $5 \cdot 2$ & $2 \cdot 5-10 \cdot 8$ & $9 \cdot 0$ & $4 \cdot 5$ & $1 \cdot 6-12 \cdot 7$ \\
\hline \multicolumn{7}{|l|}{ Tattoo } \\
\hline No & $1 \cdot 0$ & $1 \cdot 0$ & - & $1 \cdot 0$ & $1 \cdot 0$ & - \\
\hline Yes, not in prison prison/jail & $1 \cdot 2$ & $1 \cdot 6$ & $1 \cdot 1-2 \cdot 5$ & $1 \cdot 4$ & 1.7 & $0 \cdot 9-2 \cdot 9$ \\
\hline Yes, in prison/jail & $3 \cdot 1$ & $2 \cdot 3$ & $1 \cdot 4-3 \cdot 8$ & $5 \cdot 0$ & $3 \cdot 4$ & $1 \cdot 6-7 \cdot 5$ \\
\hline
\end{tabular}

* Univariate odds ratios exclude all observations with missing values in multivariate model.

$\dagger$ Variable not included in multivariate model; not significant.

\$ Bernalillo County (1996) compared with Southeast (1997).

from $13.5 \%$ among those aged $15-19$ to $78.9 \%$ among those aged 45 or more, and for HCV from $29.7 \%$ to $89.4 \%$ in the same age groups. The increase in HBV was roughly steady with increasing age, whereas HCV antibody positivity rose more sharply and then essentially levelled in the early 30 s as shown in Figure $2 a$.

As shown in Table 2, the patterns of $\mathrm{HBV}$ and $\mathrm{HCV}$ antibody prevalence were similar within each behavioural characteristic, and all were statistically significant, except the variable relating to primary sharing partner. As expected, individuals who reported sharing injection equipment were more likely to be infected with HBV $(63.7 \%)$ and HCV $(85.2 \%)$ than those who did not $(38.1 \%$ and $56.3 \%$ respectively). Interestingly, individuals who primarily used heroin, either alone or mixed with cocaine, were more likely to be infected with HBV and HCV than individuals who primarily used only cocaine and/or amphetamines. The seroprevalence of both HBV and $\mathrm{HCV}$ was strongly associated with the number of years of injection, with HBV increasing from $23.5 \%$ with 1-4 years of injecting drug use to $82.5 \%$ after $30+$ years of use, and $\mathrm{HCV}$ increasing from $51.7 \%$ to $90.6 \%$ in the same groups (Fig. $2 b$ ). Remarkably, $97 \cdot 3 \%$ (107 of 110$)$ of the individuals who reported injecting for 25-29 years were infected with HCV.

As indicated above, most of the participants in this street-based survey had tattoos, and these were strongly associated with both HBV and HCV antibody positivity (Table 2). Most of the increased risk associated with tattoos appeared to result from acquisition of tattoos in jail or prison. Individuals who received tattoos in jail/prison had the highest 
HBV seroprevalence of $76.7 \%$, compared to 52.4 $56.5 \%$ if tattoos were received other than in jail/ prison and $51.4 \%$ if no tattoo was reported. The HCV antibody prevalence was $93.2 \%$ among individuals with tattoos from jail/prison, $72 \cdot 7-85 \cdot 7 \%$ with tattoos other than jail/prison, and $73.3 \%$ if no tattoos were reported.

Past year number of reported sexual partners was also associated with $\mathrm{HBV}$ and HCV. Persons reporting zero partners had the highest seroprevalence, with decreasing seroprevalence through the 5-9 partner category, and then increasing through the $50+$ partner group.

Results of multivariate logistic regression modelling are shown in Table 3. Most of the patterns described in the univariate analysis above and in Tables 1 and 2 are maintained in the multivariate analysis. One exception is gender which was not significantly associated with either $\mathrm{HBV}$ or $\mathrm{HCV}$ in multivariate models. Noteworthy were the strong independent associations of years of injection and heroin use with both HBV and HCV antibody positivity. A significant association was also observed with having received tattoos in jail/prison (OR for $\mathrm{HBV}=2 \cdot 3,95 \% \mathrm{CI}$ $1.4-3.8$ and $\mathrm{OR}$ for $\mathrm{HCV}=3.4,95 \%$ CI $1.6-7 \cdot 5$ ). Interestingly, while sharing injection equipment was strongly associated with $\mathrm{HCV}$, its association with $\mathrm{HBV}$ antibody positivity was not significant $(\mathrm{OR}=$ $1 \cdot 3,95 \%$ CI $0 \cdot 7-2 \cdot 3)$. Sharing injection equipment was retained in the final multivariate model because of its clear behavioural link to HBV infection in other reports.

In models for monoinfection with $\mathrm{HBV}$ and $\mathrm{HCV}$ the same general results as above were supported, although the power was decreased because of the smaller number of persons infected with only HBV $(n=17)$ or only HCV $(n=169)$. In the model for $\mathrm{HBV} / \mathrm{HCV}$ coinfection, the associations with most risk factors were stronger than in the models in Table 3. Of particular note were the associations with having received tattoos in jail/prison $(\mathrm{OR}=6.0,95 \% \mathrm{CI}$ $2 \cdot 2-16 \cdot 4$ ), having received tattoos other than in jail/prison $(\mathrm{OR}=2 \cdot 1,95 \% \mathrm{CI} 1 \cdot 04-4 \cdot 2)$, use of heroin $(\mathrm{OR}=2 \cdot 9,95 \% \mathrm{CI} 1 \cdot 4-6 \cdot 2)$, and sharing of injection equipment $(\mathrm{OR}=3 \cdot 1,95 \%$ CI $1 \cdot 4-7 \cdot 1)$.

\section{DISCUSSION}

We have shown a high prevalence of HBV and HCV antibodies with continuing low prevalence of HIV infection among IDUs in New Mexico, a multi-ethnic and mostly rural population in the southwestern US.
The risk of $\mathrm{HCV}$ infection in particular reached a very high level ( $>86 \%$ ) by approximately 30 years of age. Hispanic IDUs, the majority group in this streetbased survey, were at particularly high risk for both $\mathrm{HBV}$ and $\mathrm{HCV}$ infection. We also confirmed in this study the well-established associations between years of injecting drug use and sharing of injection equipment and HBV and HCV antibody positivity.

The association of both HBV and HCV with age and with years of injection is noteworthy because of the strong statistical significance and the important public health implications. As shown in Figure $2 a$, $\mathrm{HCV}$ antibody prevalence increases very quickly to over $50 \%$ by age 20 , suggesting that interventions aimed at preventing infection will only be successful if they reach young IDUs early in their drug injecting experience. Several studies have consistently noted a positive association between $\mathrm{HCV}$ antibody prevalence and the duration of injecting drug use, presumably a measure of the cumulative exposure [2, 17-21]. Adolescent IDUs also appear to be at exceptionally high risk of $\mathrm{HCV}$ infection in incident studies [7, 13]. The full range of harm reduction programmes must be available to younger users, including access to drug treatment programmes [22].

A strong association was observed between having a tattoo and both HBV and HCV antibody positivity, and $\mathrm{HBV} / \mathrm{HCV}$ coinfection, particularly a tattoo received in prison (HBV: $\mathrm{OR}=2 \cdot 3,95 \% \mathrm{CI} 1 \cdot 4-3 \cdot 8$; $\mathrm{HCV}: \quad \mathrm{OR}=3.4, \quad 95 \%$ CI $1.6-7 \cdot 5 ; \mathrm{HBV} / \mathrm{HCV}$ coninfection: $\mathrm{OR}=6 \cdot 0,95 \%$ CI $2 \cdot 2-16 \cdot 4)$. Since tattooing in jail or prison is generally performed using non-sterile equipment such as paper clips and guitar strings, it is not surprising that this practice would be a risk factor for acquisition of bloodborne pathogens, as has been seen in Spain [23]. In other countries, $\mathrm{HCV}$ infection has been associated with folk medicine practices, tattooing, body piercing and commercial barbering [24-31]. However, in the United States, case-control studies have generally reported no association between $\mathrm{HCV}$ and these types of exposures [32-34]. A case-control study conducted in New Mexico of risk factors for sporadic $\mathrm{HCV}$ infection did find a significant association between the presence of tattoos and $\mathrm{HCV}$ infection, even after adjustment for potential confounding factors [35]. To our knowledge, the current report is the first one among US drug users to document a significant association between receipt of tattoos, especially in jail or prison, and HBV and $\mathrm{HCV}$. A high prevalence of tattoos, usually performed illegally and/or in prison, has also been noted among persons attending certain HIV outpatient clinics [36] 
and a recent study among fishermen in Thailand found a significant association between HIV-1 seroprevalence and having a tattoo [37]. The strong association between tattoos received in prison and bloodborne pathogens may in part be confounded by other high-risk behaviour in prison or may be a consequence of an association between history of imprisonment and chaotic and dangerous lifestyles. In either case, this association deserves further investigation to assess how preventing the spread of bloodborne viruses should be better dealt with in prison environments [7, 38].

Surprisingly, the sharing of injection equipment was not statistically significant in the multivariate analysis for HBV. While this practice is undoubtedly a risk factor for $\mathrm{HBV}$ and $\mathrm{HCV}$ transmission, problems with recall or the time reference of the question may have resulted in non-differential misclassification leading to bias towards the null [39]. We found a strong association between use of heroin (compared to cocaine or amphetamines only) and HBV and HCV seroprevalence among IDUs in New Mexico. In contrast, several studies have reported an association between cocaine injecting and bloodborne viral infections [13, 40-42]. It is likely that behavioural factors (e.g. higher-risk injecting practices and partners) are responsible for the increased risk observed with certain drugs in various populations. In New Mexico, there is an urgent need for ethnographic research into the sharing of syringes, dissolved drug doses, and use of cottons and cookers among IDUs who inject primarily heroin.

Because of its known association with bloodborne infections, we attempted to assess the relationship between sexual activity and HBV and HCV infection in this study. Unfortunately, the only sexual history data collected in this street-based survey was the number of partners during the past year and this variable was by-and-large inversely correlated with infection. This unexpected inverse correlation may be explained by unmeasured confounders, including clinical illness and/or extensive substance use affecting sexual activity. When we included sexual activity in multivariate models the odds ratios for other variables did not change.

As with any convenience sample, this study has the limitations of being a self-selected group and may not represent all injecting drug users, even in New Mexico. Participants in the study were those willing to interact with public health agency representatives, and some individuals may have been motivated by the small payment for participation. Most of the outreach workers were Hispanic former IDUs, which may have influenced the participants they recruited.

The public health outreach activity and the data summarized in this report have been influential in developing Department of Health policy related to bloodborne pathogens among IDUs in New Mexico. Specifically, the high HBV and HCV infection rates indicate an enormous current public health problem and suggest that action must be taken to prevent the problem from extending to HIV. Based in part on these findings, the 1997 New Mexico Legislature amended drug paraphernalia law to allow for legal syringe exchange programmes to be conducted in the State, and the bill was signed into law by the State Governor. Since that time, harm reduction programmes that include legal syringe exchange have been implemented predominantly in those communities in which the seroprevalence surveys reported here were conducted. By the end of 2000, almost 4000 IDUs had been enrolled in New Mexico syringe exchange programmes, and approximately 800000 syringes had been exchanged. The data presented here support the need for expanded community outreach programmes targetting young drug users, prevention of initiation of drug injection, and risk reduction counselling and bloodborne virus testing for IDUs and their sexual partners [20, 43].

\section{ACKNOWLEDGEMENTS}

The authors gratefully acknowledge the study participants in New Mexico; the staff of the New Mexico Department of Health laboratory; the New Mexico Street Outreach Program (NM/STOP), particularly Richard Arellano, and other community-based organizations involved with these programmes. We also wish to thank Dr C. Mack Sewell, Martha Tanuz, Jill Gatwood, Mark Stenger, and Nick Keller of the New Mexico Department of Health and Nadine Ulibarri-Keller and Dr Lucy Bradley-Springer of the University of New Mexico School of Medicine for their help with the project and Dr Richard Garfein of the Centers for Disease Control and Prevention, for helpful comments on the manuscript.

\section{REFERENCES}

1. Mann JM, Tarantola DJ, eds. AIDS in the World II. New York: Oxford University Press, 1996: 57-70, $264-7$. 
2. Garfein RS, Vlahov D, Galai N, Doherty M, Nelson KE. Viral infections in short-term drug users: the prevalence of hepatitis $\mathrm{B}$, hepatitis $\mathrm{C}$, human immunodeficiency, and human T-lymphotropic viruses. Am J Publ Hlth 1996; 86: 655-61.

3. Nicolosi A, Musicco M, Saracco A, Molinari S, Nicolette Z, Lazzarin A. Incidence and risk factors of HIV seroconversion: a prospective study of seronegative drug users from Milan and northern Italy, 1987-1989. Epidemiol 1990; 1: 453-9.

4. Van Ameijden EJ, Watters JK, van den Hoek JA, Coutinho RA. Interventions among injection drug users: do they work? AIDS 1995; 9 (suppl A): S75-84.

5. Gerberding JL. Incidence and prevalence of human immunodeficiency virus, hepatitis $\mathrm{B}$ virus, hepatitis $\mathrm{C}$ virus, and cytomegalovirus among health care personnel at risk for blood exposure: final report from a longitudinal study. J Infect Dis 1994; 170: 1410-7.

6. Coutinho RA. HIV and hepatitis $\mathrm{C}$ among injecting drug users: success in preventing HIV has not been mirrored for hepatitis C. BMJ 1998; 317: 424-5.

7. Van Beek I, Dwyer R, Dore GJ, Luo K, Kaldor JM. Infection with HIV and hepatitis $\mathrm{C}$ virus among injecting drug users in a prevention setting: retrospective cohort study. BMJ 1998; 317: 433-7.

8. Alter MJ, Moyer LA. The importance of preventing hepatitis $\mathrm{C}$ virus infection among injection drug users in the United States. J Acquir Immune Defic Syndr Hum Retrovirol 1998; 18 (Suppl 1): S6-10.

9. Alter MJ, Kruszon-Moran D, Nainan OV, et al. The prevalence of hepatitis $\mathrm{C}$ virus infection in the United States, 1988 through 1994. N Engl J Med 1999; 341: 556-62.

10. Poynard T, Bedossa P, Opolon P. Natural history of liver fibrosis progression in patients with chronic hepatitis C. Lancet 1997; 349: 825-32.

11. Alter MJ, Margolis HS, Krawczynski K, et al. The natural history of community-acquired hepatitis $\mathrm{C}$ in the United States. N Engl J Med 1992; 327: 1899-905.

12. El-Serag HB, Mason AC. Rising incidence of hepatocellular carcinoma in the United States. N Engl J Med 1999; 10: 745-50.

13. Garfein RS, Doherty MC, Monterroso ER, Thomas DL, Nelson KE, Vlahov D. Prevalence and incidence of hepatitis $\mathrm{C}$ virus infection among young adult injection drug users. J Acquir Immune Defic Syndr Hum Retrovirol 1998; 18 (Suppl 1): S11-9.

14. Hull HF, Lyons LH, Mann JM, et al. Incidence of hepatitis B in the Penitentiary of New Mexico. Am J Publ Hlth 1985; 75: 1213-4.

15. New Mexico HIV/AIDS Epidemiologic Profile Appendix 1996. New Mexico Department of Health, 1996: 46-7.

16. Selvin S. Statistical analysis of epidemiologic data, 2nd ed. New York, NY: Oxford University Press, 1996: 243-69.

17. Van Beek I, Buckley R, Stewart M, MacDonald M, Kaldor J. Risk factors for hepatitis $\mathrm{C}$ virus infection among injecting drug users in Sydney. Genitourin Med 1994; 70: 321-4.
18. Crofts N, Stewart T, Hearne P, Ping XY, Breschkin AM, Locarnini SA. Spread of bloodborne viruses among Australian prison entrants. BMJ 1995; 310: 285-8.

19. Giradi E, Zaccarelli M, Tossini G, Puro V, Narciso P, Visco G. Hepatitis $C$ virus infection in intravenous drug users: prevalence and risk factors. Scand J Infect Dis 1990; 22: 751-2.

20. Van den Hoek JA, van Haaskecht HJ, Goudsmit J, de Wolf F, Coutinho RA. Prevalence, incidence, and risk factors of hepatitis $C$ virus infection among drug users in Amsterdam. J Infect Dis 1990; 162: 823-6.

21. Zeldis JB, Jain S, Kuramoto IK, et al. Seroepidemiology of viral infections among intravenous drug users in northern California. West J Med 1992; 156: 30-5.

22. Jones TS, Vlahov D. Use of sterile syringes and aseptic drug preparation are important components of HIV prevention among injection drug users. J Acquir Immune Defic Syndr Hum Retrovirol 1998; 18 (suppl 1): $\mathrm{S} 1-5$.

23. Pallas J, Farinas-Alvarez C, Prieto D, et al. Risk factors for monoinfections and coinfections with HIV, hepatitis $\mathrm{B}$ and hepatitis $\mathrm{C}$ viruses in northern Spanish prisoners. Epidemiol Infect 1999; 123: 95-102.

24. Kaldor JM, Archer GT, Buring ML, et al. Risk factors for hepatitis $\mathrm{C}$ virus infection in blood donors: a casecontrol study. Med J Aust 1992; 157: 227-30.

25. Kiyosawa K, Tanaka E, Sodeyama T, et al. Transmission of hepatitis $\mathrm{C}$ in an isolated area in Japan: community-acquired infection. Gastroenterol 1994; 106: $1596-602$.

26. Mele A, Sagliocca L, Manzillo G, et al. Risk factors for acute non-A, non-B hepatitis and their relationship to antibodies for hepatitis $\mathrm{C}$ virus: a case-control study. Am J Publ Hlth 1994; 84: 1640-3.

27. Mansell CJ, Locarnini SA. Epidemiology of hepatitis C in the east. Semin Liver Dis 1995; 155: 15-32.

28. Tumminelli F, Marcellin P, Rizzo S, et al. Shaving as a potential source of hepatitis $\mathrm{C}$ virus infection. Lancet 1995; 345: 658.

29. Stroffolini T, Menchinelli M, Taliani G, et al. High prevalence of hepatitis $\mathrm{C}$ virus infection in a small central Italian town: lack of evidence of parenteral exposure. Ital J Gastroenterol Hepatol 1995; 27 : 235-8.

30. Mele A, Corona R, Tosti ME, et al. Beauty treatments and risk of parenterally transmitted hepatitis: results from the hepatitis surveillance system in Italy. Scand $\mathbf{J}$ Infect Dis 1995; 27 : 441-4.

31. Sun DX, Zhang FG, Geng YQ, Xi DS. Hepatitis C transmission by cosmetic tattooing in women. Lancet 1996; 347: 541 .

32. Centers for Disease Control and Prevention. Recommendations for prevention and control of hepatitis $\mathrm{C}$ virus (HCV) infection and $\mathrm{HCV}$-related chronic disease. MMWR 1998; 47 (RR-19): 1-39.

33. Alter MJ, Gerety RJ, Smallwood L, et al. Sporadic nonA, non-B hepatitis: frequency and epidemiology in an urban United States population. J Infect Dis 1982; 145: 886-93. 
34. Alter MJ, Coleman PJ, Alexander WJ, et al. Importance of heterosexual activity in the transmission of hepatitis B and non-A non-B hepatitis. JAMA 1989; 262: 1201-5.

35. Balasekaran R, Bulterys M, Jamal M, et al. A casecontrol study of risk factors for sporadic hepatitis $\mathrm{C}$ virus infection in the southwestern United States. Am J Gastroenterol 1999; 94: 1341-6.

36. Perkins CJ, Schiff S, Steger KA, Craven DE. Tattoos in HIV-infected persons: new insights into an old art. International AIDS Conference, Vancouver, Abstract Tu. C.2662.

37. Entz AT, Ruffolo VP, Chinveschakitvanich V, Soskolne V, van Griensven GPG. HIV-1 prevalence, HIV-1 subtypes and risk factors among fishermen in the Gulf of Thailand and the Andaman Sea. AIDS 2000; 14: 1027-34.
38. Kondro W. Needle exchange advocated for Canada's prisons. Lancet 1999; 354: 1887.

39. Rothman KJ. Modern epidemiology. Boston, MA: Little, Brown, 1986: 220.

40. Rezza G, Sagliocca L, Zaccarelli M, et al. Incidence rate and risk factors for $\mathrm{HCV}$ seroconversion among injecting drug users in an area with low HIV seroprevalence. Scand J Infect Dis 1996; 28: 27-9.

41. Chaisson RE, Bacchetti P, Osmond D, et al. Cocaine use and HIV infection in intravenous drug users in San Francisco. JAMA 1989; 261: 561-5.

42. Battjes RJ, Pickens RW, Haverbos HW, et al. HIV risk factors among injecting drug users in five U. S. cities. AIDS 1994; 8: 681-7.

43. Moss AR, Hahn JA. Invited commentary: Needle exchange - No help for hepatitis? Am J Epidemiol 1999; 149: 214-6. 